\title{
Transfer and Reactivity of Hydrogen Sulfide with Immobilized Hemeproteins in Polymeric Matrix
}

\author{
Jennifer Vargas-Santiago, Juan López-Garriga* \\ Department of Chemistry, University of Puerto Rico, Mayaguez, Puerto Rico \\ Email: ^Juan.lopez16@upr.edu
}

How to cite this paper: Vargas-Santiago, J. and López-Garriga, J. (2019) Transfer and Reactivity of Hydrogen Sulfide with Immobilized Hemeproteins in Polymeric Matrix. Journal of Encapsulation and Adsorption Sciences, 9, 109-126.

https://doi.org/10.4236/jeas.2019.92006

Received: May 29, 2019

Accepted: June 24, 2019

Published: June 27, 2019

Copyright ( 2019 by author(s) and Scientific Research Publishing Inc. This work is licensed under the Creative Commons Attribution International License (CC BY 4.0).

http://creativecommons.org/licenses/by/4.0/

\begin{abstract}
Hydrogen sulfide $\left(\mathrm{H}_{2} \mathrm{~S}\right)$ has been related to be toxic and to have a role in human physiological functions. Therefore, there is a necessity to comprehend ways to scavenger hydrogen sulfide from different media. Here, we used recombinant metaquo-Hemoglobin I (metHbI) from Lucina pectinata and metaquo-myoglobin (metMb) encapsulated in the tetramethyl orthosilicate gel (TMOS), to facilitate the understanding of $\mathrm{H}_{2} \mathrm{~S}$ transfer toward these metaquo-hemeproteins. In this sol-gel environment, metHbI binds and releases $\mathrm{H}_{2} \mathrm{~S}$ with rate constants of $0.0597 \mathrm{M}^{-1} \cdot \mathrm{s}^{-1}$ and $6.67 \times 10^{-5} \mathrm{~s}^{-1}$, respectively. The process generates an $\mathrm{H}_{2} \mathrm{~S}$ affinity constant $\left(\mathrm{k}_{\mathrm{on}} / \mathrm{k}_{\mathrm{off}}\right)$ of $8.9 \times$ $10^{2} \mathrm{M}^{-1}$, which is $10^{7}$ lowers than the analogous constant in solution $\left(6.3 \times 10^{9}\right.$ $\mathrm{M}^{-1}$ ). Although the $\mathrm{H}_{2} \mathrm{~S} \mathrm{k}_{\text {off }}$ for the $\mathrm{rHbI}-\mathrm{H}_{2} \mathrm{~S}$ complex is almost similar with both sol-gel and solution. To further understand how the $\mathrm{H}_{2} \mathrm{~S}_{\text {off }}$ from rHbI- $\mathrm{H}_{2} \mathrm{~S}$ in solution $(5 \mu \mathrm{M})$ is influenced by the protein concentration gradient, metHbI and metMb $(25 \mu \mathrm{M})$ encapsulated in TMOS sol-gel. Under these circumstances, the $\mathrm{H}_{2} \mathrm{~S}$ transfer from a solution of the $\mathrm{rHbI}-\mathrm{H}_{2} \mathrm{~S}$ complex to encapsulated hemeprotein resulted in $\mathrm{k}_{\text {off }}$ values of $1.90 \times 10^{-4} \mathrm{~s}^{-1}$, and $2.09 \times 10^{-4} \mathrm{~s}^{-1}$ leading to the formation of $\mathrm{rHbI}-\mathrm{H}_{2} \mathrm{~S}$ and $\mathrm{Mb}-\mathrm{H}_{2} \mathrm{~S}$ species, respectively. The results suggest that the: 1 ) extreme ionic TMOS construct limits the $\mathrm{H}_{2} \mathrm{~S}$ pathways to reach the hemeprotein active center, 2) possible interaction with metHbI hydrophilic forces increases the hydrogen bonding networking and decreases the $\mathrm{H}_{2} \mathrm{~S}$ association constant, 3) hemeproteins concentration gradients between solution and sol-gels also influence its hydrogen sulfide transfer. In the presence of oxygen or hydrogen peroxide metMb generated a mixture of $\mathrm{Mb}-\mathrm{H}_{2} \mathrm{~S}$ and sulfmyoglobin derivative, while encapsulated metHbI reaction did not produce the sulfheme species. Consequently, the results show that metHbI encapsulated in TMOS is an excellent trap for $\mathrm{H}_{2} \mathrm{~S}$ from solution or gas media.
\end{abstract}




\section{Keywords}

Hydrogen sulfide, Lucina pectinata, Inorganic Polymer, Biomedical Applications, Protein Immobilization

\section{Introduction}

It is well-known that encapsulation of biomolecule, such as proteins [1] [2], enzymes [3], antibodies and cells [1], using sol-gels method is widely considered for research in the development of biosensor [4] [5] [6], tissue engineering [7], and drug delivery [8] [9]. This technique involves the inclusion of a biomolecule in an inorganic matrix where mobility is restricted but allows migration of particular analytes through the gel lattice [10] [11]. One of the main challenges in the polymeric matrix immobilization is to prevent denaturalization of biomolecules. Silica-based sol-gels are widely used to encapsulate large biomolecules at room temperature because they retain the protein structural and functional characteristics [12]. The advantage of tetramethyl orthosilicate (TMOS) is that the sol-gel cannot swell after immersion into the biomolecule's solutions, keeping the protein from leaving the framework and making it ideal for the reaction between solutions or gases [10].

Recently, snake venom was immobilized by the sol-gel method to prevent denaturation of venom content from the environmental conditions [13]. Efficiency assay, scanning electron microscopy and cytotoxicity analysis, showed that the process is suitable to encapsulate the venom and is appropriate for drug delivery systems. Another biomolecule encapsulated in silica sol-gels was cytochrome c [14] [15] [16]. UV-vis spectroscopy reveals insignificant changes in the structural conformation of the molecule encapsulated. In both types of research, biomolecules were immobilized in nanometric spaces. These provide the possibility of mimicking the environment in which proteins are sterically hindered, diffusion is reduced, and water molecules do not behave as bulk water [11] [17]. Therefore, this technique, in combination with the selectivity offers by biomolecules, could a good alternative of analyzing chemical reactions of biological interest.

Hemoglobin I ( $\mathrm{HbI}$ ) from the mollusk Lucina pectinata is a very effective heme-protein monomer for scavenging $\mathrm{H}_{2} \mathrm{~S}$, with extraordinary affinity by fast binding $\left(\mathrm{k}_{\mathrm{on}}=2.3 \times 10^{5} \mathrm{M}^{-1} \cdot \mathrm{s}^{-1}\right)$, together with very slow dissociation $\left(\mathrm{k}_{\text {off }}=0.22\right.$ $\times 10^{-3} \mathrm{~s}^{-1}$ ) to form ferric hemoglobin sulfide with absorption bands at $426 \mathrm{~nm}$, $543 \mathrm{~nm}$, and $575 \mathrm{~nm}$ [18] [19] [20] [21] [22]. This high affinity is stabilized by hydrogen bonding with $\mathrm{Gln}(64) \mathrm{E}$, and by aromatic electrostatic interactions with residues Phe(29)B10, Phe(43)CD1, and Phe(68)E11, known as the Phe-cage [23] [24]. Our research group has achieved the HbI immobilization and characterization over a conductive surface [25] [26]. Galardon and co-workers have used $\mathrm{HbI}$ for reversible detection and quantification of $\mathrm{H}_{2} \mathrm{~S}$ by fluorescence [27].

This work presents the immobilization of $\mathrm{HbI}$ from L pectinata using a sili- 
ca-based sol-gel to evaluate the binding with hydrogen sulfide and stability in the polymeric matrix. Kinetic studies by UV spectroscopy generate into the transfer of $\mathrm{H}_{2} \mathrm{~S}$ from the rHbI- $\mathrm{H}_{2} \mathrm{~S}$ complex in solution toward $\mathrm{HbI}$ encapsulated, and $\mathrm{Mb}$ encapsulated in the presence of $\mathrm{O}_{2}$ or $\mathrm{H}_{2} \mathrm{O}_{2}$. The results show the capacity of these proteins to trap $\mathrm{H}_{2} \mathrm{~S}$ with a relatively small association rate constant comparative to the same protein in solution. Also, attenuated total reflection Fourier transform infrared spectroscopy (ATR-FTIR) analysis confirms the structural conservation of protein after the encapsulation. In general, these results suggest that $\mathrm{HbI}$ can scavenge $\mathrm{H}_{2} \mathrm{~S}$ with good stability even when it is in a crowded surrounding such a silica cage environment.

\section{Materials and Methods}

\subsection{Sample Preparation}

The expression of the recombinant $\mathrm{HbI}$ His-tagged and purification used in the experiment has been described in detail previously [28]. The metaquo-HbI (metHbI) and metaquo-Mb (metMb) from the equine skeletal muscle (Sigma Aldrich) were prepared by heme oxidation, adding $10 \%$ molar excess of potassium ferricyanide solution and after the reaction, the oxidant was removed with an Amicon ${ }^{\circledR}$ device. The protein was in a $100 \mathrm{mM}$ phosphate buffer at $\mathrm{pH} 6.5$. The experiments were performed with $\mathrm{H}_{2} \mathrm{~S}$ present in solution and gas phase. The $\mathrm{H}_{2} \mathrm{~S}$ stock solution of $0.4 \mathrm{mM}$ was prepared by dissolving $\mathrm{Na}_{2} \mathrm{~S} \cdot 9 \mathrm{H}_{2} \mathrm{O}$ salt (Alfa Aesar) in the buffer. The buffer for the $\mathrm{H}_{2} \mathrm{~S}$ stock solution contained 100 mM succinic acid (Sigma Aldrich), $100 \mathrm{mM}$ potassium dihydrogen phosphate (Sigma Aldrich) and $1 \mathrm{mM}$ EDTA (Sigma Aldrich) adjusted to $\mathrm{pH}$ 6.5. The stock solution was purged and degassed to prevent oxygen contamination. Different aliquots $(10-20 \mu \mathrm{L})$ of the $\mathrm{H}_{2} \mathrm{~S}$ stock solution were added to encapsulate metHbI to form rHbI- $\mathrm{H}_{2} \mathrm{~S}$ complex, where $\mathrm{H}_{2} \mathrm{~S}$ had a 5 to 2000 -fold molar excess compared to the protein's concentration. The $\mathrm{H}_{2} \mathrm{~S}$ gas was prepared by the reaction of $\mathrm{Na}_{2} \mathrm{~S}$ with concentrated $\mathrm{HCl}$ in a vial. The $\mathrm{H}_{2} \mathrm{~S}$ gas produced was transferred carefully to the sample through the tube by creating a small difference in pressure between the vials, using a syringe in the sample container. The hemeprotein hydrogen sulfide complex was formed by bubbling small amounts of $\mathrm{H}_{2} \mathrm{~S}$ gas directly into the hemoglobin sample from another container. The $32 \mathrm{mM}$ hydrogen peroxide (Sigma Aldrich) stock solution) was prepared by measuring the aliquot in a vial and dissolving it with buffer. An Agilent $8453 \mathrm{UV}$-Vis spectrophotometer was used to confirm the presence of the metHbI and $\mathrm{rHbI}-\mathrm{H}_{2} \mathrm{~S}$. Beer-Lambert law was used to determine the concentration of metHbI and metMb in solutions, using 178 and $188 \mathrm{~cm}^{-1} \cdot \mathrm{M}^{-1}$ as the heme molar absorptivity, respectively [29].

\subsection{Protein Immobilization by Sol-Gel Method}

Immobilization was accomplished as reported in the literature [15] [30]. Briefly, $2 \mathrm{~mL}$ of TMOS (99\%, Acros Organics) as the silicon-containing precursor fol- 
lowed by the addition of $1 \mathrm{~mL}$ of $2 \mathrm{mM} \mathrm{HCl}$ (Sigma Aldrich) as a catalytic acid were mixed at room temperature. The mixture was sonicated at $4^{\circ} \mathrm{C}$ for $15 \mathrm{mi}-$ nutes and purged by bubbling an $\mathrm{N}_{2}$ flow for 15 minutes. The equal volumetric ratio of resulting sol and protein stock solutions were used to create two gels at each end of the plastic cuvette as described in Scheme 1. The bottom gel was prepared by simultaneously mixing TMOS and $50 \mu \mathrm{M}$ protein solution in a plastic cuvette. Several minutes after it was mixed, gelation occurred, obtaining $25 \mu \mathrm{M}$ of protein concentration. Then, the cuvette was covered with a septum and flipped upside-down to add the mixture with a syringe, creating a second sol-gel at the top of the cuvette only. This free space between both ends was represented by the area of the dot in the scheme. In that space, the plastic cuvette was perforated with a tin welder to add $\mathrm{rHbI}-\mathrm{H}_{2} \mathrm{~S}$ solution through a septum without disturbing the gel. This $\mathrm{rHbI}-\mathrm{H}_{2} \mathrm{~S}$ solution donated the $\mathrm{H}_{2} \mathrm{~S}$ toward encapsulated metHbI and metMb to generate the complex rHbI- $\mathrm{H}_{2} \mathrm{~S}$ or sulfmyoglobin (in the presence of peroxide), respectively. Scheme 1(d) shows how the protein is entrapment in the sol-gel method. The gel encloser the protein, and it interacts with water and hydrogen bond of the hydrophilic nanopores [31]. In the experiment, the $\mathrm{H}_{2} \mathrm{~S}$ heme complex and immobilized heme protein were monitored by absorption spectra. Similarly, $\mathrm{H}_{2} \mathrm{~S}$ was also applied in a gas state to monitor the binding of the gas to the hemeprotein encapsulated in the sol-gel. The polymers were stored in the refrigerator at $4^{\circ} \mathrm{C}$. Figure 1 shows the hemeprotein encapsulated within TMOS.
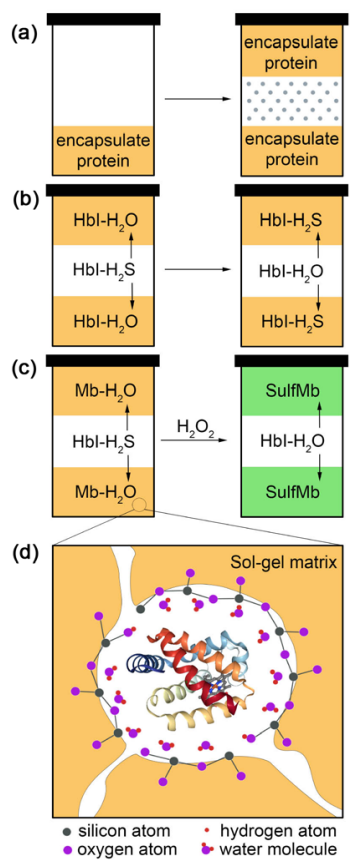

Scheme 1. Protein immobilization method. (a) TMOS and $50 \mu \mathrm{M}$ protein solutions (metHbI or metMb) were mixed in an equal volumetric ratio to create two sol-gels at each end of the plastic cuvette. The dots area is a free space where $\mathrm{rHbI}-\mathrm{H}_{2} \mathrm{~S}$ is added to donate $\mathrm{H}_{2} \mathrm{~S}$ toward protein encapsulated, generating $\mathrm{rHbI}-\mathrm{H}_{2} \mathrm{~S}$ complex (b) and sulfmyoglobin, in the presence of $\mathrm{O}_{2}$ or $\mathrm{H}_{2} \mathrm{O}_{2}(\mathrm{c})$. In (d), the protein is enclosed by the gel, and it interacts with water and hydrogen bond of the hydrophilic nanopores. 


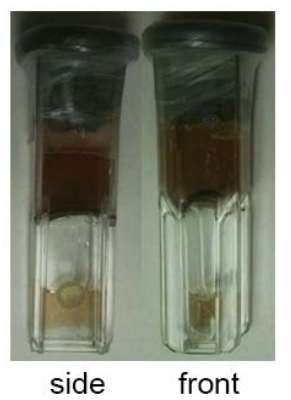

Figure 1. Encapsulation of hemeprotein inside silica-based sol-gel. The side view shows where the cuvette was performed to facilitate the solution addition without disturbing the gel.

\subsection{Protein Release Studies}

The release of encapsulated metHbI and metMb was determined by immersing the polymer in a glass vial with $400 \mu \mathrm{L}$ of phosphate buffer in $\mathrm{pH} 6.5$. The buffer was removed and concentrated by centrifuging $\left(5000 \mathrm{rpm}, 25^{\circ} \mathrm{C}\right)$ in a $3 \mathrm{~K} \mathrm{Ep}-$ pendorf micro tube until $100 \mu \mathrm{L}$ was obtained. The amount of protein in the buffer solution was measured by adding $10 \mu \mathrm{L}$ in DMV bio cell (Starna Scientific) and was analyzed employing a Shimadzu UV 2700 spectrophotometer. Then, the analyzed buffer was returned to the sol-gel, and the process was repeated for four days.

\subsection{Kinetic Measurements}

The $\mathrm{H}_{2} \mathrm{~S}$ association rate constant $\left(\mathrm{k}_{\mathrm{on}}\right)$ in encapsulated metHbI under anaerobic conditions was determined using UV-Vis spectrophotometry. The reactions were done using $25 \mu \mathrm{M}$ of metHbI encapsulated in silica gel and different $\mathrm{H}_{2} \mathrm{~S}$ solution to obtain the desired final concentrations (0.625 - $0.05 \mathrm{M})$. Excess $\mathrm{H}_{2} \mathrm{~S}$ was used to make the reaction pseudo-first order $\left(\left[\mathrm{H}_{2} \mathrm{~S}\right] \gg[\mathrm{HbI}]\right)$ as reported by Roche and Pietri [15] [21]. Spectra were collected at $426 \mathrm{~nm}$, every 30 seconds over 6 hours, to evaluate the formation of the $\mathrm{H}_{2} \mathrm{~S}$ complex. Using Origin 9, rate constant values $\left(k_{\text {obs }}\right)$ were obtained by plotting $-\ln \left(A-A_{\infty}\right)$ versus time $(s)$ for each $\mathrm{H}_{2} \mathrm{~S}$ concentration. The $\mathrm{H}_{2} \mathrm{~S} \mathrm{k}_{\text {on }}$ for $\mathrm{rHbI}-\mathrm{H}_{2} \mathrm{~S}$ in wet silica gel was obtained from the slope of $\mathrm{k}_{\mathrm{obs}}$ versus $\mathrm{H}_{2} \mathrm{~S}$ concentrations graph. The $\mathrm{H}_{2} \mathrm{~S}$ dissociation rate constant $\left(\mathrm{k}_{\text {off }}\right)$ in both solution and encapsulated $\mathrm{HbI}$ was evaluated under equilibrium conditions interacting with $\mathrm{H}_{2} \mathrm{~S}$ solution to obtain 5- or 18 -fold $\mathrm{H}_{2} \mathrm{~S}$ molar excess, respectively, the minimum $\mathrm{H}_{2} \mathrm{~S}$ concentration required to form the $\mathrm{rHbI}-\mathrm{H}_{2} \mathrm{~S}$ complex. Spectra were collected at $426 \mathrm{~nm}$ over 6 hours. A plot of $-\mathrm{ln}$ ( $A-A_{\infty}$ ) versus time gave a slope representative of $\mathrm{k}_{\text {off }}$. This value was compared with the presence of 3-fold of $\mathrm{H}_{2} \mathrm{O}_{2}$ molar excess.

\subsection{ATR-FTIR Spectroscopy}

IR spectra were measured following the protocol described by Yang [32]. A Perkin Elmer Frontier FTIR spectrometer equipped with a diamond ATR crystal and TGS detector was used to obtain spectra of metHbI and $\mathrm{rHbI}-\mathrm{H}_{2} \mathrm{~S}$ solutions 
and encapsulated $\mathrm{rHbI}-\mathrm{H}_{2} \mathrm{~S}$. Spectra were collected at $25^{\circ} \mathrm{C}$ using a resolution of $4 \mathrm{~cm}^{-1}$ and an averaging of 120 scans. All solutions and sol-gels were prepared in $\mathrm{H}_{2} \mathrm{O}$ solution. FTIR spectra of buffer solution and sol-gel without protein were subtracted from the spectra of hemoglobin HbI solutions and encapsulated HbI, respectively. A straight baseline between 2000 and $1750 \mathrm{~cm}^{-1}$ is evidence of correct water subtraction.

\section{Results and Discussions}

\subsection{Structure of HbI after Sol-Gel Encapsulation}

The work presented here examine the immobilization, release, and secondary structure of the protein encapsulate by the sol-gel method. Figure 2(a) shows the UV-Vis spectra of metHbI in solution and after encapsulation in sol-gels. In the encapsulated metHbI (black line) spectra a sharp transition at $407 \mathrm{~nm}$ and small bands at 501 and $633 \mathrm{~nm}$ can be observed. This spectrum was identical to the protein solution (blue line), demonstrating that the encapsulated protein preserves the heme configuration. The UV absorption spectra in hemoproteins are attributed to $\pi \rightarrow \pi^{*}$ electronic transitions of the heme porphyrin. In consequence, there is an intense band near to the ultraviolet region known as the Soret band, and weak electronic transitions between $500-600 \mathrm{~nm}$ called Q bands. These spectral bands are sensitive to the changes exerted by the coordination state in the iron and surrounding of the heme protein [33]. Thus, according to Gamero-Quijano, A. et al. (2014), the evidence points out that the silica framework retains its optical characteristic of the protein upon encapsulation [14] [15], suggesting that the heme porphyrin remain stable. The UV-Vis spectrum for the buffer after having contact with metHbI sol-gel (dash line) by four days showed the absence of protein bands, indicating that pore size in the silica framework kept the protein immobilized in the lattice [34]. The data present that $\mathrm{HbI}$ encapsulated in TMOS is stable, and it is not released to the solution. MetHbI immobilized in silica gel and exposed to $\mathrm{H}_{2} \mathrm{~S}$ in both solution and gas phase, showed a red shift of the Soret band at $426 \mathrm{~nm}$ and Q bands at 544 and

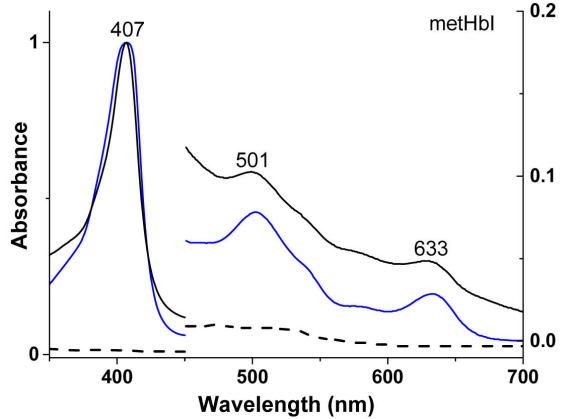

(a)

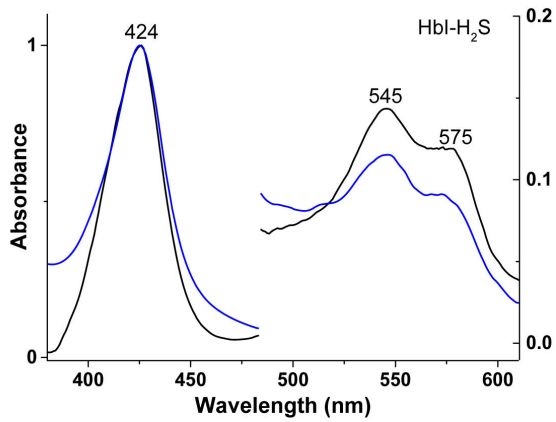

(b)

Figure 2. UV-Vis spectra for (a) metHbI and (b) $\mathrm{rHbI}_{2} \mathrm{H}_{2} \mathrm{~S}$ in solution (blue line) and post-encapsulation (black line). The dashed line represents protein release after the buffer had contact with the encapsulated metHbI for four days. 
$575 \mathrm{~nm}$ seen in Figure 2(b) [21] [27]. This supports previous findings establishing that pore size in the polymeric matrix permits diffusion of small ligands [15] [30]. Moreover, it also indicates that $\mathrm{HbI}$ should be considered to scavenge and quantify $\mathrm{H}_{2} \mathrm{~S}$.

Furthermore, ATR-FTIR technique detected secondary structure changes upon encapsulation of $\mathrm{HbI}$ and $\mathrm{rHbI}_{-} \mathrm{H}_{2} \mathrm{~S}$. Figure 3 exhibits IR spectra of metHbI solution (green line), encapsulated metHbI (blue line), $\mathrm{rHbI}_{-} \mathrm{H}_{2} \mathrm{~S}$ solution (red line), and encapsulated $\mathrm{rHbI}-\mathrm{H}_{2} \mathrm{~S}$ (black line). All spectra coincide in bands at $1650 \mathrm{~cm}^{-1}$ and $1548 \mathrm{~cm}^{-1}$ corresponding to amide I and amide II, the most prominent vibrational normal modes of the protein backbone to determine secondary structures [32] [35] [36] [37]. However, the peak intensity can change due to scattering from the gel's rough surface. This result indicates that $\alpha$-helix is the predominant secondary structure [38] [39], consistent with the values reported in the literature for the crystallographic structure of the native $\mathrm{HbI}$ [23]. This finding supports that the encapsulation using sol-gel method did not significantly alter the secondary structure in both metHbI and $\mathrm{rHbI}_{-} \mathrm{H}_{2} \mathrm{~S}$ [14] [40] [41]. The stability of the HbI monomeric protein was not affected by its encapsulation, presence of $\mathrm{H}_{2} \mathrm{~S}$, nor by pore reduction in the microenvironment [34] [41] [42] [43]. However, these results did not coincide with the changes seen in the secondary structure of $\beta$-Galactosidase upon encapsulated in silica gel [17]. This protein's structural behavior may be related to the different structural protein sizes between $\mathrm{HbI}$ and $\beta$-Galactosidase as well as changes in the non-covalent interaction inside the particular sol-gel cages [1].

This result indicates that $\alpha$-helix is the predominant secondary structure [38] [39], consistent with the values reported in the literature for the crystallographic structure of the native $\mathrm{HbI}$ [23]. This finding supports that the encapsulation using sol-gel method did not significantly alter the secondary structure in both metHbI and $\mathrm{rHbI}_{-} \mathrm{H}_{2} \mathrm{~S}$ [14] [40] [41]. The stability of the HbI monomeric protein

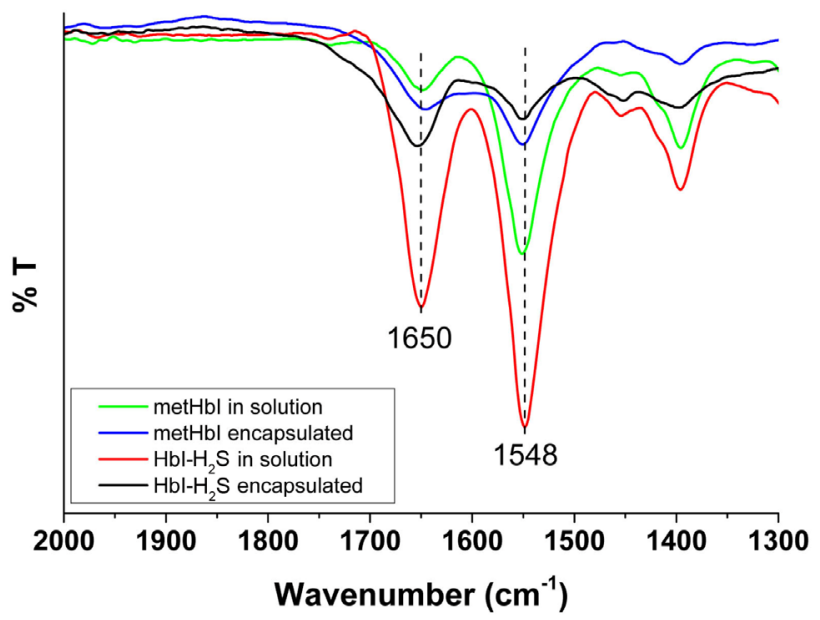

Figure 3. ATR FTIR spectra are illustrating the amide I and amide II band of complexes: metHbI in solution (green) and immobilized in sol-gel (blue), and $r \mathrm{HbI}-\mathrm{H}_{2} \mathrm{~S}$ in solution (red) and encapsulated (black). 
was not affected by its encapsulation, presence of $\mathrm{H}_{2} \mathrm{~S}$, nor by pore reduction in the microenvironment [34] [41] [42] [43]. However, these results did not coincide with the changes seen in the secondary structure of $\beta$-Galactosidase upon encapsulated in silica gel [17]. This protein's structural behavior may be related to the different structural protein sizes between $\mathrm{HbI}$ and $\beta$-Galactosidase as well as changes in the non-covalent interaction inside the particular sol-gel cages [1].

\subsection{Myoglobin Encapsulation and Reactivity}

Figure 4 shows the UV-V is spectra of metMb solution (blue line) and metMb encapsulate (black line). The data present that both has a Soret band at $409 \mathrm{~nm}$, and Q bands at $504 \mathrm{~nm}$ and $633 \mathrm{~nm}$, revealing that the encapsulation of the hemeprotein preserved the chromophore structure. Also. $\mathrm{Mb}$ protein release studies (dash line) showed that the immobilized heme-protein was retained in the polymer. These results coincide with findings previously detailed for HbI. The literature establishes that both proteins are similar in size with 142 and 152 residues for $\mathrm{HbI}$ and equine $\mathrm{Mb}$, respectively [23] [44]. Therefore, the method is very useful for trapping for both monomeric hemeproteins.

Structural studies with $\mathrm{Mb}$ active site have shown that this hemeprotein has a histidine (His) residue at the distal E7 position and Val, Phe, and Leu in the E11, $\mathrm{CD} 1$, and B10, respectively [20] [22]. Data suggest that this residue allow that metMb in the presence of $\mathrm{H}_{2} \mathrm{~S}$ and hydrogen peroxide produces the incorporation of a sulfur atom in the pyrrole $\mathrm{B}$ of the heme-porphyrin generating a species known as sulfMb. This compound has a green color and a characteristic electronic transition at $620 \mathrm{~nm} \mathrm{[20]} \mathrm{[22]} \mathrm{[45].} \mathrm{To} \mathrm{confirm} \mathrm{that} \mathrm{encapsulates} \mathrm{metMb}$ is active toward $\mathrm{H}_{2} \mathrm{~S}$, a similar experiment was performed, where this heme protein was exposed to a 1:5 ratio of $\mathrm{H}_{2} \mathrm{O}_{2}$ and $\mathrm{H}_{2} \mathrm{~S}$ solutions, respectively. Figure 4 inset shows the presence of a band at $617 \mathrm{~nm}$, which can be attributed to the

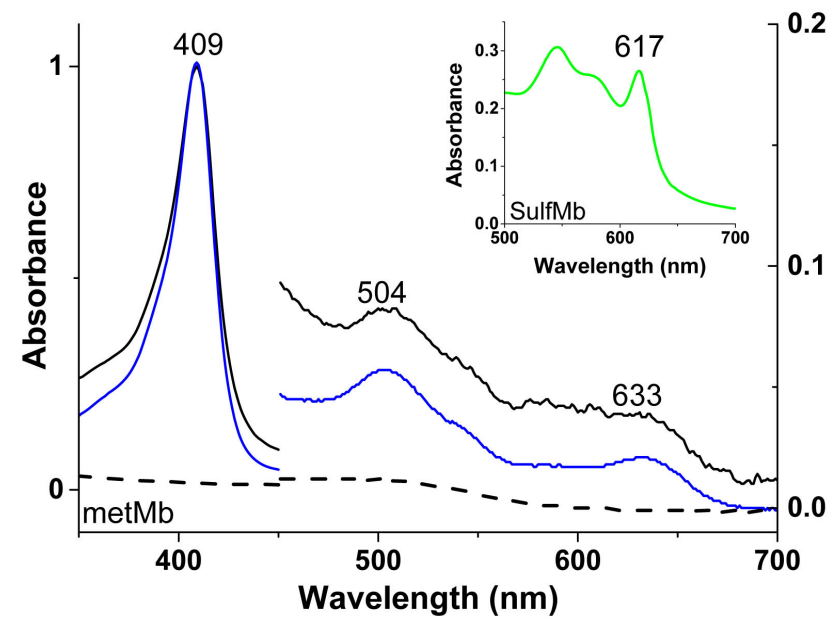

Figure 4. UV-Vis spectra for metMb in solution (blue line) and encapsulated in sol-gel (black line). The dashed line represents the spectrum of the buffer after contact with $\mathrm{Mb}$ sol-gel by four days. The inset shows evidence of sulfheme derivative produced by the reaction of encapsulated $\mathrm{Mb}$ in the presence of oxidative agent (i.e., $\mathrm{H}_{2} \mathrm{O}_{2}$ ) and $\mathrm{H}_{2} \mathrm{~S}$. 
formation of sulfmyoglobin in the polymer. Similarly, oxy-Mb upon reaction with $\mathrm{H}_{2} \mathrm{~S}$ also produces sulfMb [20] [22] [45]. However, $\mathrm{HbI}$ and $\mathrm{rHbI}$ in reacting with $\mathrm{H}_{2} \mathrm{O}_{2}$ or $\mathrm{Oxy}-\mathrm{HbI}$ and oxy-rHbI in the presence of $\mathrm{H}_{2} \mathrm{~S}$ does not form the sulfheme product [20] [46]. Therefore, caution must be present in the quantification of $\mathrm{H}_{2} \mathrm{~S}$ using the $\mathrm{MbSH}_{2}$ complex, since secondary product, i.e., sulfMb formation, could prevent a precise quantification of $\mathrm{H}_{2} \mathrm{~S}$ by $\mathrm{Mb}$. On the other hand, the data suggest that the sol-gel method represents a viable alternative to use immobilized $\mathrm{Mb}$ to analyze reactions where the proteins have steric hindrance, instead of making comparisons with reactions in a solution where the protein has free motion.

\subsection{Monitoring $\mathrm{H}_{2} \mathrm{~S}$ in Encapsulated $\mathrm{HbI}$ in Sol-Gel by Kinetic Analysis}

UV-Vis spectroscopy was used to evaluate the binding properties of encapsulated metHbI with $\mathrm{H}_{2} \mathrm{~S}$ in solution and the gas phase. For this purpose, Figure 5(a) shows the displacement of the Soret band from metHbI to $\mathrm{rHbI}-\mathrm{H}_{2} \mathrm{~S}$ complex. The shift of the $407 \mathrm{~nm}$ band as a function of time (Figure 5(b)) to $426 \mathrm{~nm}$ is confirmed the $\mathrm{H}_{2} \mathrm{~S}$ ligation. The difference in bands intensity between these two species is affected by a reduction of molar absorptivity coefficient from 178 to $102 \mathrm{~cm}^{-1} \cdot \mathrm{M}^{-1}$ for metHbI and $\mathrm{rHbI}-\mathrm{H}_{2} \mathrm{~S}$, respectively [29]. The hemeprotein retained the chromophore group functionality inside the polymeric matrix. Association kinetic studies between encapsulated metHbI and $\mathrm{H}_{2} \mathrm{~S}$ solution (Figure $5(c))$, shows a significantly slow association rate constant $\left(\mathrm{k}_{\mathrm{on}}\right)$ of $0.0579 \mathrm{M}^{-1} \cdot \mathrm{s}^{-1}$. Thus, the reaction is $10^{6}$ times slower than the $\mathrm{H}_{2} \mathrm{~S} \mathrm{k}_{\text {on }}$ for the (His) ${ }_{6}-\mathrm{HbI}$ reported in solution $\left(1.90 \times 10^{5} \mathrm{M}^{-1} \cdot \mathrm{s}^{-1}\right)$. The fast association is affected by amino acids in the active site and its periphery [47]. When the protein is immobilized,

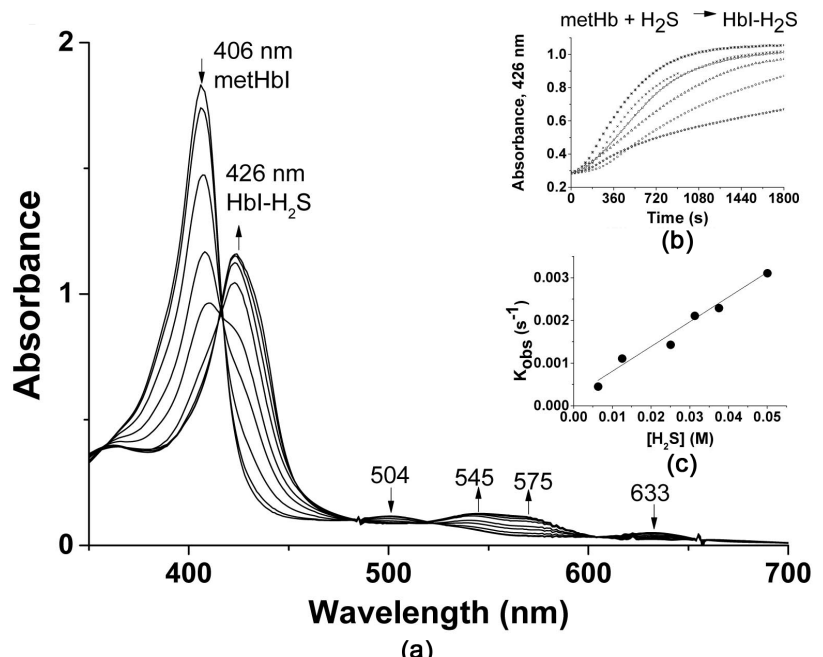

Figure 5. (a) Sequence of absorption spectra upon the reaction of encapsulated metHbI with $\mathrm{H}_{2} \mathrm{~S}$ until converting into $\mathrm{rHbI}-\mathrm{H}_{2} \mathrm{~S}$ complex; (b) Absorbance traces at $426 \mathrm{~nm}$ of the response of $\mathrm{HbI}$ at different concentrations of $\mathrm{H}_{2} \mathrm{~S}$ (from 0.625 to $5 \times 10^{-2} \mathrm{M}$ ). (c) The plot of the $\mathrm{k}_{\mathrm{obs}}$ as a function of $\mathrm{H}_{2} \mathrm{~S}$ concentration. 
the sol-gel matrix limits the diffusion, movements, accessibility of the $\mathrm{H}_{2} \mathrm{~S}$ to the heme cavity, decreasing its binding rate. The $\mathrm{k}_{\mathrm{on}}$ value when $\mathrm{H}_{2} \mathrm{~S}$ gas was used to form the heme- $\mathrm{H}_{2} \mathrm{~S}$ complex differed by a factor of 2, obtaining $0.167 \mathrm{M}^{-1} \cdot \mathrm{s}^{-1}$ (Figure S1, Supplementary Information). As a function of the $\mathrm{pH}$, the $\mathrm{Na}_{2} \mathrm{~S}$ salt dissolution is accompanied by the formation of the $\mathrm{H}_{2} \mathrm{~S}, \mathrm{HS}^{-}$, and $\mathrm{S}^{2-}$ species [48]. For example, at $\mathrm{pH} 6.5^{\circ} \mathrm{C}$ and $25^{\circ} \mathrm{C}$, the solution consists of mainly $62 \%$ $\mathrm{H}_{2} \mathrm{~S}$ and $38 \% \mathrm{HS}^{-}$. Therefore, when $\mathrm{Na}_{2} \mathrm{~S}$ is dissolved in concentrated hydrochloride acid, it generates $\mathrm{NaCl}_{(\mathrm{ac})}$ and $\mathrm{H}_{2} \mathrm{~S}_{(\mathrm{g})}$ without the contributions of other sulfides species. The process does not dismiss that while $\mathrm{H}_{2} \mathrm{~S}$ gas passes through the polymer, it can dissociate with the water produced by condensation of polymer synthesis. Hence, this established that hydrogen sulfide generated either in solution or in the polymer did not significantly alter the reaction in the sol-gel between metHbI and $\mathrm{H}_{2} \mathrm{~S}$.

The dissociation kinetics of $\mathrm{H}_{2} \mathrm{~S}$ in the encapsulated $\mathrm{HbI}$ was evaluated in first-order equilibrium conditions, with $450 \mu \mathrm{M}$ or 18 -fold $\mathrm{H}_{2} \mathrm{~S}$ molar excess, the minimum $\mathrm{H}_{2} \mathrm{~S}$ concentration required to form the $\mathrm{rHbI}-\mathrm{H}_{2} \mathrm{~S}$ complex. Figure 6 shows that the ligand exhibits very slow dissociation rate constant $\left(\mathrm{k}_{\text {off }}\right)$ of $6.67 \times$ $10^{-5} \mathrm{~s}^{-1}$, alike to counterpart, (His) $)_{6}$-HbI solution $\left(3.00 \times 10^{-5} \mathrm{~s}^{-1}\right)$. The data suggest that the equilibrium in the framework occur similar than the solution. According to Pietri, et al., (2009) [21] the hydrogen sulfide ligand dissociation from a heme group is dictated by two competing reactions involving simple dissociation of $\mathrm{H}_{2} \mathrm{~S}$. The heme ferric adduct leads to the metHbI derivative is dominated by low concentration of $\mathrm{H}_{2} \mathrm{~S}$, while the deoxy $\mathrm{HbI}$ species is present upon reduction of the heme iron by $\mathrm{H}_{2} \mathrm{~S}$ itself at high concentrations (200-2000-fold $\mathrm{H}_{2} \mathrm{~S}$ molar excess) [1]. Our results indicate that the heme- $\mathrm{H}_{2} \mathrm{~S}$ dissociation into metHbI and $\mathrm{H}_{2} \mathrm{~S}$ was promoted because there is no evidence about the heme reduction or absence of the $430 \mathrm{~nm}$ transition. Hence, the dissociation rate constant was not affected, $8.47 \times 10^{-5} \mathrm{~s}^{-1}$, when the heme- $\mathrm{H}_{2} \mathrm{~S}$ was formed using

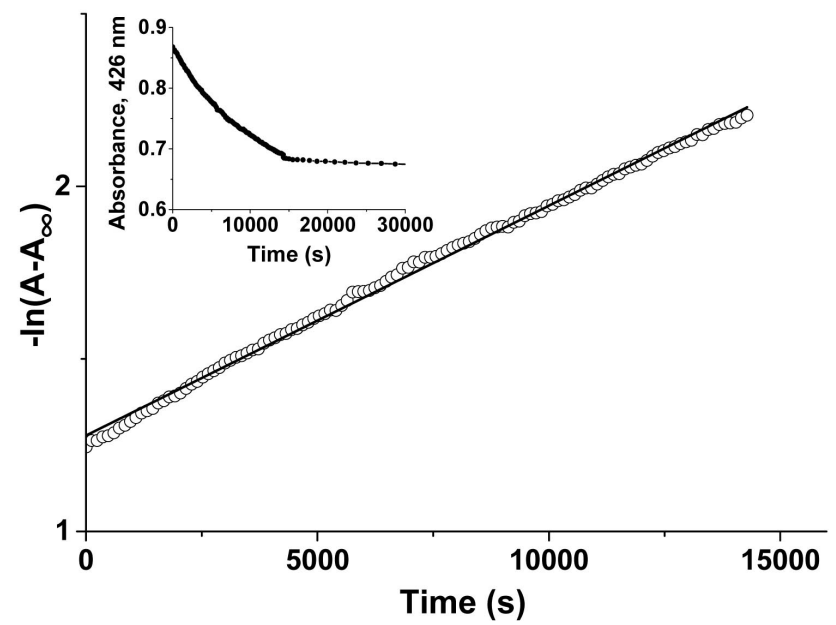

Figure 6. A plot of pseudo-first order dissociation kinetic for $\mathrm{H}_{2} \mathrm{~S}$ in encapsulated $\mathrm{HbI}$, with a positive slope of $\mathrm{k}_{\text {off }}=6.67 \times 10^{-5} \mathrm{~s}^{-1}$. Inset shows a Soret band at $426 \mathrm{~nm}$ decreasing in intensity as a function of time for a 1:18 ratio [HbI: $\left.\mathrm{H}_{2} \mathrm{~S}\right]$. 
$\mathrm{H}_{2} \mathrm{~S}$ gas (Figure S2, Supplementary Information). The outcomes suggest that the $\mathrm{HbI}$ can scavenge $\mathrm{H}_{2} \mathrm{~S}$ in both solution and gas state.

Table 1 summarizes the $\mathrm{H}_{2} \mathrm{~S}$ binding and dissociation rate constants in $\mathrm{Mb}$ and recombinants His-tag rHbI and Lys-tag rHbI. Structural studies have shown that $\mathrm{Mb}$ has slower $\mathrm{H}_{2} \mathrm{~S}$ association and faster dissociation rate constant due to the presence of His in the distal site [20]. Hence, the rapid association together slow dissociation in the $\mathrm{HbI}$ is generated by glutamine and phenylalanines near the heme. Recent kinetics studies and SAXS/WAXS data have demonstrated that both recombinants Lys and His-tagged, conserve the structural and functional characteristics of the wild type hemeprotein [49]. When (His) ${ }_{6}-\mathrm{rHbI}$ is encapsulated, the $\mathrm{H}_{2} \mathrm{~S}$ association constant was slower than hemeprotein in solution by the limited accessibility to the heme cavity; however, the (His) ${ }_{6}-\mathrm{rHbI}-\mathrm{H}_{2} \mathrm{~S}$ dissociation was almost not affected by the gel.

\subsection{Hydrogen Sulfide Transfer from $\mathrm{rHbI}_{-} \mathrm{H}_{2} \mathrm{~S}$ Solution to Encapsulated $\mathrm{rHbI}$ and $\mathrm{Mb}$}

The work examined if $25 \mu \mathrm{M}$ of encapsulated metHbI enhances the dissociation of $\mathrm{H}_{2} \mathrm{~S}$ from the $5 \mu \mathrm{M} \mathrm{rHbI}-\mathrm{H}_{2} \mathrm{~S}$ complex in solution. Although $\mathrm{rHbI}-\mathrm{H}_{2} \mathrm{~S}$ in solution generates the $100 \%$ metHbI, suggesting that $\mathrm{H}_{2} \mathrm{~S}$ is transferred to the encapsulate metHbI, Figure 7 shows an $\mathrm{H}_{2} \mathrm{~S} \mathrm{k}_{\text {off }}$ for the $\mathrm{rHbI}-\mathrm{H}_{2} \mathrm{~S}$ derivatives of

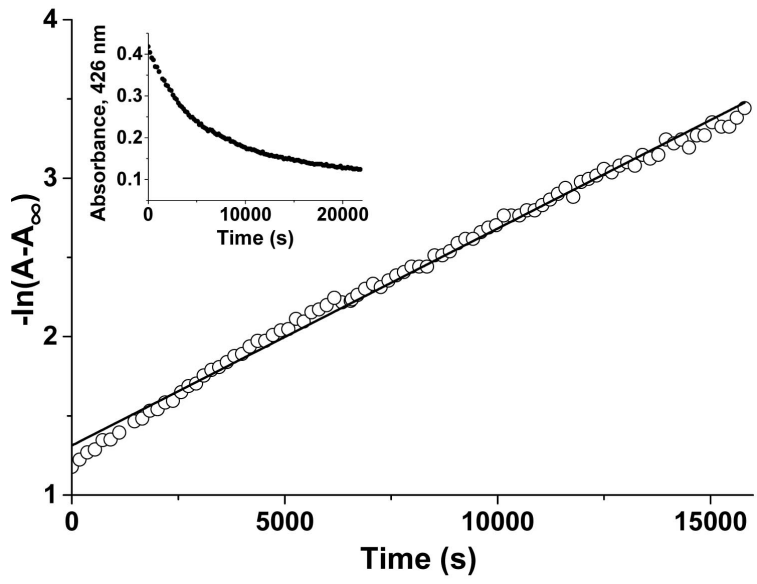

Figure 7. A plot of pseudo-first order dissociation kinetic of $\mathrm{rHbI}_{2} \mathrm{H}_{2} \mathrm{~S}$ complex in solution when it interacted with $25 \mu \mathrm{M}$ of encapsulated metHbI.

Table 1. Comparison of association and dissociation rate constants of $\mathrm{H}_{2} \mathrm{~S}$ complex in different environments.

\begin{tabular}{cccc}
\hline Protein & $\mathrm{k}_{\mathrm{on}}\left(\mathrm{M}^{-1} \cdot \mathrm{s}^{-1}\right)$ & $\mathrm{k}_{\mathrm{off}}\left(\mathrm{s}^{-1}\right)$ & Ref. \\
\hline Whale Mb (solution) & $15.9 \times 10^{3}$ & 1.6 & {$[50][51]$} \\
wt-HbI (solution) & $2.30 \times 10^{5}$ & $2.20 \times 10^{-4}$ & {$[21]$} \\
$(\mathrm{His})_{6}$-rHbI (solution) & $1.90 \times 10^{5}$ & $3.00 \times 10^{-5}$ & {$[21]$} \\
$\left(\right.$ Lys) ${ }_{6}$-rHbI (solution) & $1.40 \times 10^{5}$ & $1.00 \times 10^{-4}$ & {$[21]$} \\
$(\mathrm{His})_{6}$-rHbI (encapsulated) + interacting with $\mathrm{H}_{2} \mathrm{~S}$ (gas) & 0.167 & $8.47 \times 10^{-5}$ & This work \\
$(\mathrm{His})_{6}$-rHbI (encapsulated) + interacting with $\mathrm{H}_{2} \mathrm{~S}$ (solution) & 0.0579 & $6.67 \times 10^{-5}$ & This work \\
\hline
\end{tabular}


$1.90 \times 10^{-4} \mathrm{~s}^{-1}$, which is comparable to the solution dissociation rate reported for rHbI, $3.00 \times 10^{-5} \mathrm{~s}^{-1}$. Therefore, a concentration gradient of $20 \mu \mathrm{M}$ between the $\mathrm{rHbI}-\mathrm{H}_{2} \mathrm{~S}$ complex and encapsulated $\mathrm{rHbI}$ induces a small increase (a factor of 10) in the unbinding rate of $\mathrm{H}_{2} \mathrm{~S}$ from the $\mathrm{rHbI}-\mathrm{H}_{2} \mathrm{~S}$ from the solution although the polymeric trapped species had a higher concentration than it's analogous in solution. The same experiment was executed with encapsulated metMb, obtaining a similar $\mathrm{H}_{2} \mathrm{~S} \mathrm{k}_{\text {off }}, 2.09 \times 10^{-4} \mathrm{~s}^{-1}$. Also, $\mathrm{H}_{2} \mathrm{~S} \mathrm{k}_{\text {off }}$ was evaluated with $\mathrm{H}_{2} \mathrm{O}_{2}$, an oxidant of biological interest. In the presence of $25 \mu \mathrm{M}$ or 5 -fold $\mathrm{H}_{2} \mathrm{~S}$, and $15 \mu \mathrm{M}$ or 3-fold of $\mathrm{H}_{2} \mathrm{O}_{2}$ molar excess concerning $\mathrm{rHbI}$ concentration in solution, the $\mathrm{H}_{2} \mathrm{~S} \mathrm{k}_{\text {off }}$ was $1.19 \times 10^{-4} \mathrm{~s}^{-1}$, also indicating that the oxidative capacity of $\mathrm{H}_{2} \mathrm{O}_{2}$ did not affect the $\mathrm{H}_{2} \mathrm{~S}$ rate constant unbinding significantly. Therefore, this suggests the use of $\mathrm{HbI}$ to trap $\mathrm{H}_{2} \mathrm{~S}$ in biological samples since the amounts of $\mathrm{H}_{2} \mathrm{O}_{2}$ present in these will not have a significant effect in the slow dissociation rate constant.

\section{Conclusion}

Recombinant Hemoglobin I from the mollusk Lucina pectinata was successfully immobilized in silica-based sol-gels. The technique provided an optically transparent matrix capable of being analyzed in ATR-IR and UV-Vis. Monitoring the kinetics of $\mathrm{H}_{2} \mathrm{~S}$ in encapsulated $\mathrm{HbI}$, it was shown that the association was slower than the reaction in solution. However, the dissociation rate constant was almost not affected by the polymer and neither in the presence of a relatively small concentration of $\mathrm{H}_{2} \mathrm{O}_{2}$. The results suggest that the recombinant $\mathrm{HbI}$ can be used for $\mathrm{H}_{2} \mathrm{~S}$ scavenge both solution and gas state without inducing changes in the protein. One possible application of this work is the use of $\mathrm{HbI}$ and sol-gel technique to quantify $\mathrm{H}_{2} \mathrm{~S}$ based in optical studies. As future work, small spots printed on a surface will allow building a high throughput to quantify $\mathrm{H}_{2} \mathrm{~S}$ with the $\mathrm{rHbI}$ upon the formation of the $\mathrm{rHbI}-\mathrm{H}_{2} \mathrm{~S}$ complex followed by UV-vis spectroscopy.

\section{Acknowledgements}

This work was supported in part by the Sloan Foundation and BioXFEL Scholarship. We are thankful to Darya Marchany, Lisa Torres, Lysmarie Santos, and Hazel M. Borges for their technical assistance during the expression and purification of the recombinant $\mathrm{HbI}$.

\section{Conflicts of Interest}

The authors declare no conflicts of interest regarding the publication of this paper.

\section{References}

[1] Kandimalla, V.B., Tripathi, V.S. and Ju, H. (2006) Immobilization of Biomolecules in Sol-Gels: Biological and Analytical Applications. Critical Reviews in Analytical 
Chemistry, 36, 73-106. https://doi.org/10.1080/10408340600713652

[2] Ronda, L., Bruno, S., Campanini, B., Mozzarelli, A., Abbruzzetti, S., Viappiani, C., Cupane, A., Levantino, M. and Bettati, S. (2015) Immobilization of Proteins in Silica Gel: Biochemical and Biophysical Properties. Current Organic Chemistry, 19, $15-18$.

[3] Homaei, A.A., Sariri, R., Vianello, F. and Stevanato, R. (2013) Enzyme Immobilization: An Update. Journal of Chemical Biology, 6, 185-205. https://doi.org/10.1007/s12154-013-0102-9

[4] Peng, H., Huang, Z., Zheng, Y., Chen, W., Liu, A. and Lin, X. (2014) A Novel Nanocomposite Matrix Based on Graphene Oxide and Ferrocene-Branched Organically Modified Sol-Gel/Chitosan for Biosensor Application. Journal of Solid State Electrochemistry, 18, 1941-1949. https://doi.org/10.1007/s10008-014-2415-1

[5] Velychko, T.P., Soldatkin, O.O., Melnyk, V.G., Marchenko, S.V., Kirdeciler, S.K., Akata, B., Soldatkin, A.P., El'skaya, A.V. and Dzyadevych, S.V. (2016) A Novel Conductometric Urea Biosensor with Improved Analytical Characteristic Based on Recombinant Urease Adsorbed on Nanoparticle of Silicalite. Nanoscale Research Letters, 11, 1-6. https://doi.org/10.1186/s11671-016-1310-3

[6] Doong, R.A. and Tsai, H.C. (2001) Immobilization and Characterization of Sol-Gel-Encapsulated Acetylcholinesterase Fiber-Optic Biosensor. Analytica Chimica Acta, 434, 239-246. https://doi.org/10.1016/S0003-2670(01)00853-4

[7] Premnath, P., Tan, B. and Venkatakrishnan, K. (2012) Bioactive Interlinked Extracellular Matrix-Like Silicon Nano-Network Fabricated by Femtosecond Laser Synthesis. BioResearch Open Access, 1, 231-238.

https://doi.org/10.1089/biores.2012.0254

[8] Castro, Y., Vazquez, N.I. and Gonzalez, Z. (2017) Synthesis of Mesoporous Silica Nanoparticles by Sol-Gel as Nanocontainer for Future Drug Delivery Applications. Boletín de la Sociedad Española de Cerámica y Vidrio, 56, 139-145. https://doi.org/10.1016/j.bsecv.2017.03.002

[9] Friedman, A.J., Han, G., Navati, M.S., Chacko, M., Gunther, L., Alfieri, A. and Friedman, J.M. (2008) Sustained Release Nitric Oxide Releasing Nanoparticles: Characterization of a Novel Delivery Platform Based on Nitrite Containing Hydrogel/Glass Composites. Nitric Oxide, 19, 12-20. https://doi.org/10.1016/j.niox.2008.04.003

[10] Lázár, I. and Szabó, H.J. (2018) Prevention of the Aggregation of Nanoparticles during the Synthesis of Nanogold-Containing. Gels, 4, 1-9. https://doi.org/10.3390/gels4020055

[11] Eggers, D.K. and Valentine, J.S. (2001) Crowding and Hydration Effects on Protein Conformation: A Study with Sol-Gel Encapsulated Proteins. Journal of Molecular Biology, 314, 911-922. https://doi.org/10.1006/jmbi.2001.5166

[12] McClements, D.J. (2018) Encapsulation, Protection, and Delivery of Bioactive Proteins and Peptides Using Nanoparticle and Microparticle Systems: A Review. Advances in Colloid and Interface Science, 253, 1-22.

https://doi.org/10.1016/j.cis.2018.02.002

[13] Cigdem, C., Keçeciler, C., Karis, M., Gocmen, B., Yesil-Celiktas, O. and Nalbantsoy, A. (2018) Cytotoxicity of Silica Nanoparticles with Transcaucasian Nose-Horned Viper, Vipera ammodytes transcaucasiana, Venom on U87MG and SHSY5Y Neuronal Cancer Cells. Applied Biochemistry and Biotechnology, 186, 350-357. https://doi.org/10.1007/s12010-018-2742-2

[14] Gamero-Quijano, A., Huerta, F., Morallo, E. and Montilla, F. (2014) Modulation of 
the Silica Sol-Gel Composition for the Promotion of Direct Electron Transfer to Encapsulated Cytochrome c. Langmuir, 30, 10531-10538. https://doi.org/10.1021/la5023517

[15] Roche, C.J. and Friedman, J.M. (2010) Nitric Oxide NO Reactions with Sol-Gel and Solution Phase Samples of the Ferric Nitrite Derivative of HbA. Nitric Oxide, 22, 180-190. https://doi.org/10.1016/j.niox.2009.11.003

[16] Ronda, L., Bruno, S., Faggiano, S., Bettati, S. and Mozzarelli, A. (2008) Oxygen Binding to Heme Proteins in Solution, Encapsulated in Silica Gels, and in the Crystalline State. Methods in Enzymology, 437, 311-328. https://doi.org/10.1016/S0076-6879(07)37016-X

[17] Burgos, M.I., Ochoa, A. and Perillo, M.A. (2019) $\beta$-Sheet to $\alpha$-Helix Conversion and Thermal Stability of $\beta$-Galactosidase Encapsulated in a Nanoporous Silica Gel. Biochemical Biophysical Research Communications, 508, 270-274. https://doi.org/10.1016/j.bbrc.2018.11.077

[18] Wittenbergs, B. (1990) Hemoglobins of the Lucina Pectinata/Bacteria Symbiosis I. Journal of Biological Chemistry, 265, 16043-16053.

[19] Boubeta, F.M., Bari, S.E., Estrin, D.A. and Boechi, L. (2016) Access and Binding of $\mathrm{H}_{2} \mathrm{~S}$ to Hemeproteins: The Case of HbI of Lucina pectinata. Journal of Physical Chemistry B, 120, 9642-9653. https://doi.org/10.1021/acs.jpcb.6b06686

[20] Ríos-González, B.B., Román-Morales, E.M., Pietri, R. and López-Garriga, J. (2014) Hydrogen Sulfide Activation in Hemeproteins: the Sulfheme Scenario. Journal of Inorganic Biochemistry, 133, 78-86. https://doi.org/10.1016/j.jinorgbio.2014.01.013

[21] Pietri, R., Lewis, A., León, R.G., Casabona, G., Kiger, L., Yeh, S.-R., Fernandez-Alberti, S., Marden, M.C., Cadilla, C.L. and López-Garriga, J. (2009) Factors Controlling the Reactivity of Hydrogen Sulfide with Hemeproteins. Biochemistry, 48, 4881-4894. https://doi.org/10.1021/bi801738j

[22] Pietri, R., Román-Morales, E. and López-Garriga, J. (2011) Hydrogen Sulfide and Hemeproteins: Knowledge and Mysteries. Antioxidants \& Redox Signaling, 15, 393-404. https://doi.org/10.1089/ars.2010.3698

[23] Bolognesi, M., Rosano, C., Losso, R., Borassi, A., Rizzi, M., Wittenberg, J.B., Boffi, A. and Ascenzi, P. (1999) Cyanide Binding to Lucina pectinata Hemoglobin I and to Sperm Whale Myoglobin: An X-ray Crystallographic Study. Biophysical Journal, 77, 1093-1099. https://doi.org/10.1016/S0006-3495(99)76959-6

[24] Rizzi, M., Wittenberg, J.B., Coda, A., Fasano, M., Ascenzi, P. and Bolognesi, M. (1994) Structure of the Sulfide-Reactive Hemoglobin from the Clam Lucina pectinata: Crystallographic Analysis at $1.5 \AA$ Resolution. Journal of Molecular Biology, 244, 86-99. https://doi.org/10.1006/jmbi.1994.1706

[25] Torres-Gonzalez, L., Diaz, R., Vega-Olivencia, C.A. and Lopez-Garriga, J. (2018) Characterization of Recombinant His-Tag Protein Immobilized onto Functionalized Gold Nanoparticles. Sensors, 18, 4264. https://doi.org/10.3390/s18124262

[26] Diaz-Ayala, R., Torres-Gonzalez, L., Pietri, R., Cabrera, C.R. and Lopez-Garriga, J. (2017) Engineered (Lys) ${ }_{6}$-Tagged Recombinant Sulfide-Reactive Hemoglobin I for Covalent Immobilization at Multiwalled Carbon Nanotubes. ACS Omega, 2, 9021-9032. https://doi.org/10.1021/acsomega.7b01500

[27] Dulac, M., Armelle, M. and Galardon, E. (2018) Reversible Detection and Quantification of Hydrogen Sulfide by Fluorescence Using the Hemoglobin I from Lucina pectinata. ACS Sensors, 3, 2138-2144. https://doi.org/10.1021/acssensors.8b00701

[28] León, R.G., Munier-Lehmann, H., Barzu, O., Baudin-Creuza, V., Pietri, R., 
López-Garriga, J. and Cadilla, C.L. (2004) High-Level Production of Recombinant Sulfide-Reactive Hemoglobin I from Lucina pectinata in Escherichia coli: High Yields of Fully Functional Holoprotein Synthesis in the BLi5 E. coli Strain. Protein Expression and Purification, 38, 184-195. https://doi.org/10.1016/S1046-5928(04)00301-8

[29] Wittenbergg, B. and Jing-Fen, L. (1990) Hemoglobins of the Lucina pectinata/Bacteria Symbiosis. Journal of Biological Chemistry, 265, 16054-16059.

[30] Roche, C.J., Dantsker, D., Samuni, U. and Friedman, J.M. (2006) Nitrite Reductase Activity of Sol-Gel-Encapsulated Deoxyhemoglobin: Influence of Quaternary and Tertiary Structure. Journal of Biological Chemistry, 281, 36874-36882. https://doi.org/10.1074/jbc.M603914200

[31] Dickson, D.J. and Ely, R.L. (2013) Silica Sol-Gel Encapsulation of Cyanobacteria: Lessons for Academic and Applied Research. Applied Microbiology and Biotechnology, 97, 1809-1819. https://doi.org/10.1007/s00253-012-4686-8

[32] Yang, H., Yang, S., Kong, J., Dong, A. and Yu, S. (2015) Obtaining Information about Protein Secondary Structures in Aqueous Solution using Fourier Transform IR Spectroscopy. Nature Protocols, 10, 382-396.

https://doi.org/10.1038/nprot.2015.024

[33] Gouterman, M. (1961) Spectra of Porphyrins I. Journal of Molecular Spectroscopy, 6, 138-163. https://doi.org/10.1016/0022-2852(61)90236-3

[34] Martelli, T., Ravera, E., Louka, A., Cerofolini, L., Hafner, M., Fragai, M., Becker, C.F.W. and Luchinat, C. (2016) Atomic-Level Quality Assessment of Enzymes Encapsulated in Bioinspired Silica. Chemistry-A European Journal, 22, 425-432. https://doi.org/10.1002/chem.201503613

[35] Nevskaya, N.A. and Chirgadze, Y.N. (1976) Infrared Spectra and Resonance Interactions of Amide I and II Vibrations of $\alpha$-Helix. Biopolymers, 15, 637-648. https://doi.org/10.1002/bip.1976.360150404

[36] Kong, J. and Yu, S. (2007) Fourier Transform Infrared Spectroscopic Analysis of Protein Secondary Structures. Acta Biochimica et Biophysica Sinica, 39, 549-559. https://doi.org/10.1111/j.1745-7270.2007.00320.x

[37] Zeeshan, F., Tabbassum, M., Jorgensen, L. and Medlicott, N.J. (2018) Attenuated Total Reflection Fourier Transform Infrared (ATR FT-IR) Spectroscopy as an Analytical Method to Investigate the Secondary Structure of a Model Protein Embedded in Solid Lipid Matrices. Applied Spectroscopy, 72, 268-279. https://doi.org/10.1177/0003702817739908

[38] Jackson, M. and Mantsch, H.H. (1995) The Use and Misuse of FTIR Spectroscopy in the Determination of Protein Structure. Critical Reviews in Biochemistry Molecular Biology, 30, 95-120. https://doi.org/10.3109/10409239509085140

[39] Goormaghtigh, E., Ruysschaert, J. and Raussens, V. (2006) Evaluation of the Information Content in Infrared Spectra for Protein Secondary Structure Determination. Biophysical Journal, 90, 2946-2957. https://doi.org/10.1529/biophysj.105.072017

[40] Tu, J., Boyle, A.L., Friedrich, H., Bomans, P.H.H., Bussmann, J., Sommerdijk, N.A.J.M., Jiskoot, W. and Kros, A. (2016) Mesoporous Silica Nanoparticles with Large Pores for the Encapsulation and Release of Proteins. ACS Applied Materials and Interfaces, 8, 32211-32219. https://doi.org/10.1021/acsami.6b11324

[41] Vanea, E., Gruian, C., Rickert, C., Steinhoff, H.J. and Simon, V. (2013) Structure and Dynamics of Spin-Labeled Insulin Entrapped in a Silica Matrix by the Sol-Gel Method. Biomacromolecules, 14, 2582-2592. https://doi.org/10.1021/bm4003893 
[42] Ashtari, K., Khajeh, K., Fasihi, J., Ashtari, P., Ramazani, A. and Vali, H. (2012) Silica-Encapsulated Magnetic Nanoparticles: Enzyme Immobilization and Cytotoxic Study. International Journal of Biological Macromolecules, 50, 1063-1069. https://doi.org/10.1016/j.ijbiomac.2011.12.025

[43] Samuni, U., Roche, C.J., Dantsker, D., Juszczak, L.J. and Friedman, J.M. (2006) Modulation of Reactivity and Conformation within the T Quaternary State of $\mathrm{Hu}$ man Hemoglobin: The Combined Use of Mutagenesis and Sol-Gel Encapsulation. Biochemistry, 45, 2820-2835. https://doi.org/10.1021/bi050010i

[44] Unno, M., Chen, H., Kusama, S., Shaik, S. and Ikeda-Saito, M. (2007) Structural Characterization of the Fleeting Ferric Peroxo Species in Myoglobin: Experiment and Theory. Journal of the American Chemical Society, 129, 13394-13395. https://doi.org/10.1021/ja076108x

[45] Lopez-Garriga, J., Wymore, T., Pietri, R., Roman-Morales, E.M., Rios-Gonzalez, B. and Arbelo, H. (2014) P90 Hydrogen Sulfide Activation by Hemeproteins: Implications of the Sulfheme Scenario. Nitric Oxide, 39, S43.

https://doi.org/10.1016/j.niox.2014.03.140

[46] Román-Morales, E., López-Alfonzo, E., Pietri, R. and López-Garriga, J. (2016) Sulfmyoglobin Conformational Change: A Role in the Decrease of Oxy-Myoglobin Functionality. Biochemistry Biophysics Reports, 7, 386-393.

https://doi.org/10.1016/j.bbrep.2016.07.002

[47] Fernandez-Alberti, S., Bacelo, D.E., Binning, R.C., Echave, J., Chergui, M. and Lopez-Garriga, J. (2006) Sulfide-Binding Hemoglobins: Effects of Mutations on Active-Site Flexibility. Biophysical Journal, 91, 1698-1709. https://doi.org/10.1529/biophysj.106.081646

[48] Nagy, P., Pálinkás, Z., Nagy, A., Budai, B., Tóth, I. and Vasas, A. (2014) Chemical Aspects of Hydrogen Sulfide Measurements in Physiological Samples. Biochimica et Biophysica Acta, 1840, 876-891. https://doi.org/10.1016/j.bbagen.2013.05.037

[49] Díaz-Ayala, R., Moya-Rodríguez, A., Pietri, R., Cadilla, C.L. and López-Garriga, J. (2015) Molecular Cloning and Characterization of a (Lys) ${ }_{6}$-Tagged Sulfide-Reactive Hemoglobin I from Lucina pectinata. Molecular Biotechnology, 57, 1050-1062. https://doi.org/10.1007/s12033-015-9896-8

[50] Bostelaar, T., Vitvitsky, V., Kumutima, J., Lewis, B.E., Yadav, P.K., Brunold, T.C., Filipovic, M., Lehnert, N., Stemmler, T.L. and Banerjee, R. (2017) Hydrogen Sulfide Oxidation by Myoglobin. Journal of the American Chemical Society, 138, 8476-8488. https://doi.org/10.1021/jacs.6b03456

[51] Jensen, B. and Fago, A. (2018) Reactions of Ferric Hemoglobin and Myoglobin with Hydrogen Sulfide under Physiological Conditions. Journal of Inorganic Biochemistry, 182, 133-140. https://doi.org/10.1016/j.jinorgbio.2018.02.007 


\section{Supporting Information}

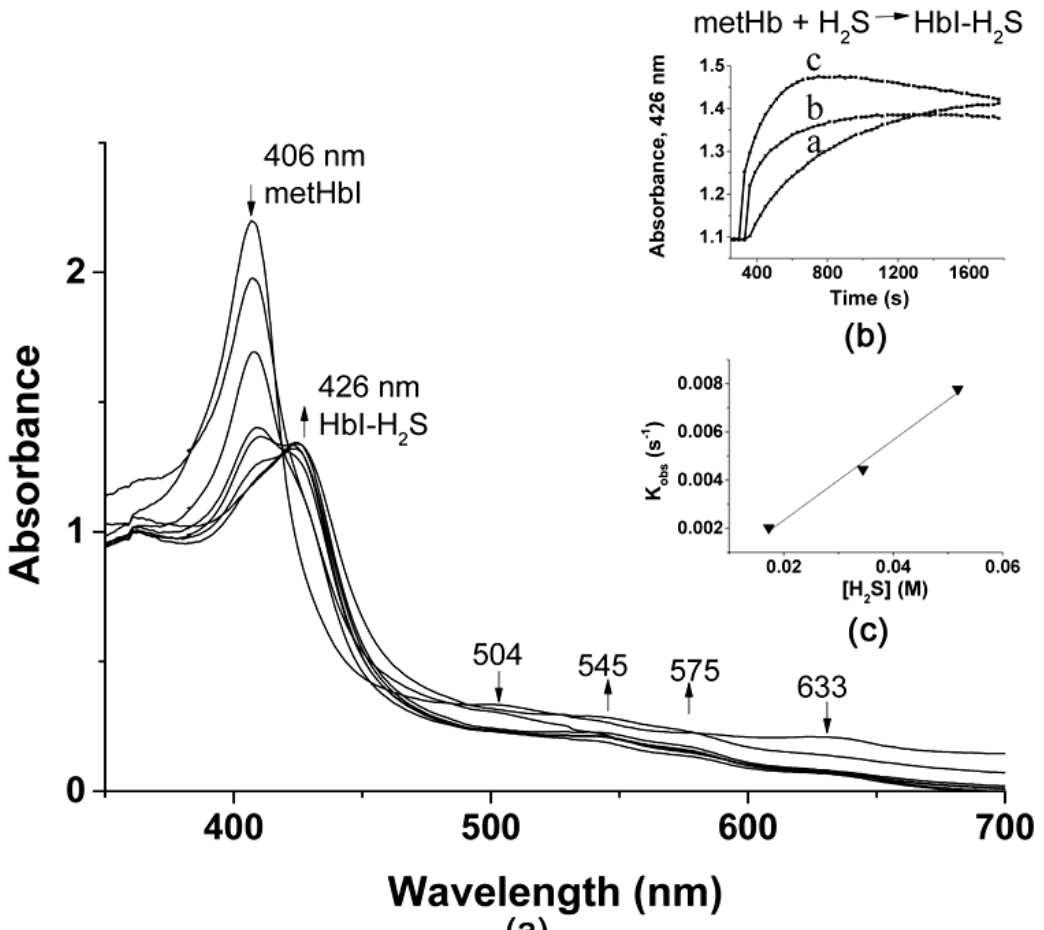

(b)

(c)

(a)

Figure S1. (a) A sequence of UV-Vis spectra of metHbI in sol-gel reacting with $\mathrm{H}_{2} \mathrm{~S}$ in gas until converting into $\mathrm{HbI}-\mathrm{H}_{2} \mathrm{~S}$ complex. The transition of met-aquoHbI appears at 406, 504, and $633 \mathrm{~nm}$, while in $\mathrm{HbI}-\mathrm{H}_{2} \mathrm{~S}$ complex, they appear at 426, 545, and $575 \mathrm{~nm}$. (b) Kinetic traces for $426 \mathrm{~nm}$ following molar ratios of a: 1:40, b: 1:80, c: 1:120. (c) The plot of the observed association rate constants as a function of $\mathrm{H}_{2} \mathrm{~S}$ concentration, $\mathrm{k}_{\text {on }}$ $\left(0.167 \mathrm{~s}^{-1}\right)$.

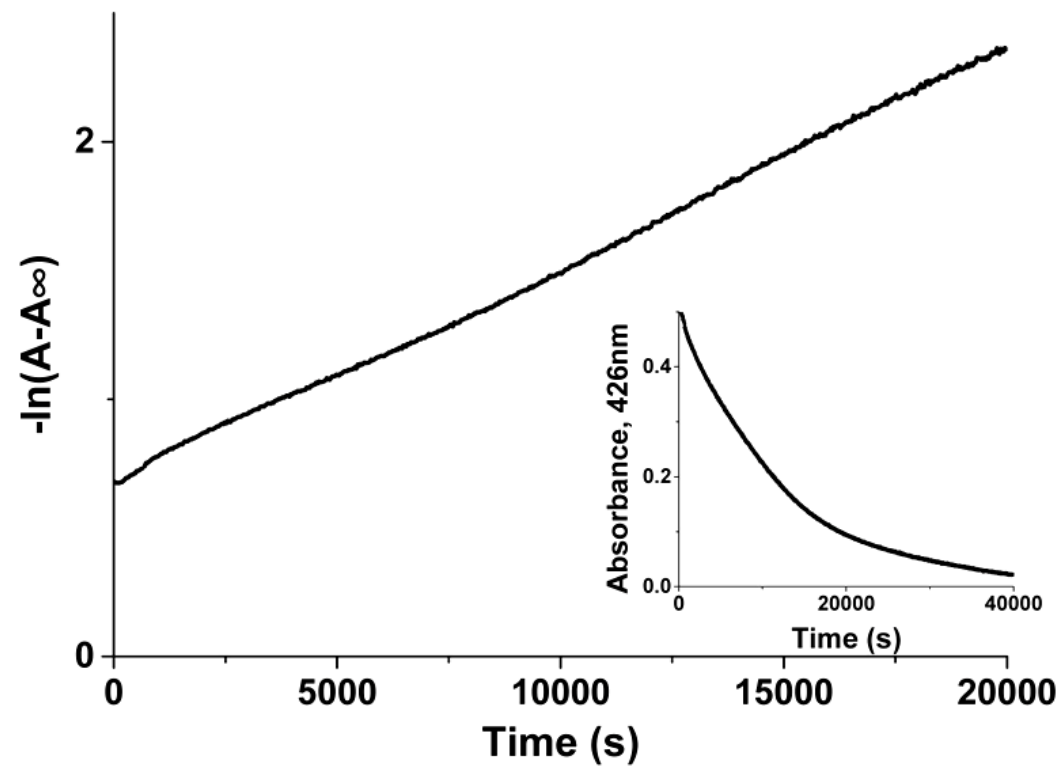

Figure S2. A plot of pseudo-first order dissociation kinetic for $\mathrm{H}_{2} \mathrm{~S}$ in the encapsulated $\mathrm{HbI}-\mathrm{H}_{2} \mathrm{~S}$ complex created with $\mathrm{H}_{2} \mathrm{~S}$ gas. The positive slope is $\mathrm{k}_{\text {off }}, 8.47 \times 10^{-5} \mathrm{~s}^{-1}$. The inset displays that the absorbance trace at $426 \mathrm{~nm}$ decreases in intensity as a function of time. 


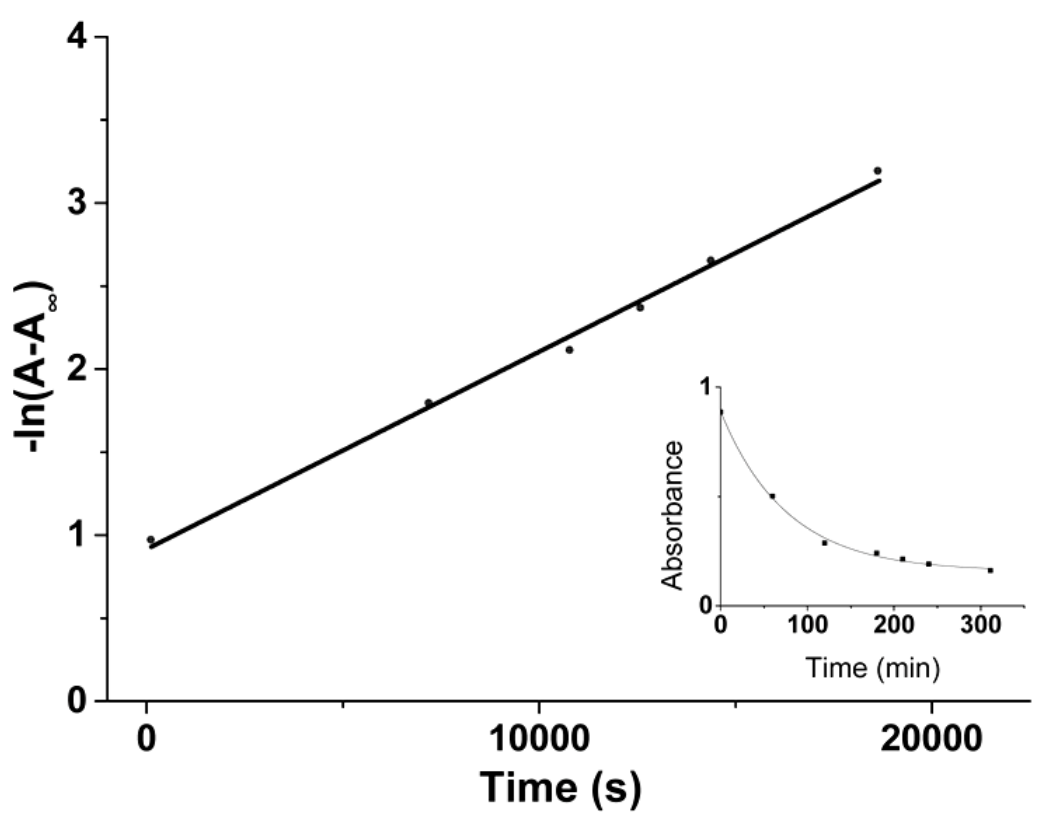

Figure S3. A plot of pseudo-first order dissociation kinetic for $\mathrm{H}_{2} \mathrm{~S}$ in $\mathrm{HbI}-\mathrm{H}_{2} \mathrm{~S}$ complex solution in the presence of $15 \mu \mathrm{M}$ or 3-fold of $\mathrm{H}_{2} \mathrm{O}_{2}$ when it interacts with encapsulated $\mathrm{Mb}$. The positive slope is $\mathrm{k}_{\text {off }}, 0.119 \times 10^{-3} \mathrm{~s}^{-1}$. The inset displays the kinetic traces at 426 $\mathrm{nm}$ for the unbinding of $\mathrm{HbI}-\mathrm{H}_{2} \mathrm{~S}$ complex as a function of time. 